\title{
A Stylistic Analysis of Arab-American Poetry: Mahjar (Place of Emigration) Poetry
}

\author{
Ibrahim Abushihab \\ English Department, Faculty of Arts, Alzaytoonah University of Jordan, Amman, Jordan
}

\begin{abstract}
The present paper represents an attempt to focus upon analyzing and describing the major features of Arab American poetry written by prominent Arab poets who had arrived in America on behalf of millions of immigrants during the $19^{\text {th }}$ century. Some of who wrote in English and Arabic like Ameen Rihani (18761940); Khalil Gibran (1883-1931) and Mikhail Naimy (1889-1988). Others wrote in Arabic like Elia Abumadi (1890-1957). Most of their poems in Mahjar (place of emigration) reveal nostalgia, their love to their countries and their ancestors and issues relating to Arab countries. The paper analyzes some of their poems based on linguistic, grammatical, lexical and rhetorical levels.
\end{abstract}

Index Terms — style, rhetoric, stylistics, discourse stylistics, Arab American poetry and Mahjar poets

\section{INTRODUCTION}

Stylistics focuses on analyzing literary works based on linguistic views. It covers three major elements: Literary Studies, Literary Criticism and Linguistic Schools. Verma (2015) states that stylistics is a language-based approach. It benefits from linguistic issues like sentence types and phonological, morphological, lexical and rhetorical elements to analyze and interpret literary works. Language is the source of linguistics but it is a medium in literature. To link language with stylistics, Beaugrande and Dressler (1986) state seven standards which make any text communicative. These standards are called standards of textuality. Some of which are:

- Coherence: referring to the configuration of concepts and relations of the text.

- Intentionality: referring to the attitude of the text writer.

- Acceptability: referring to the attitude of the text reader.

- Intertextuality: referring to the elements which link the current text to previously encountered texts.

Stylistic analysis directs the reader to literary criticism which is the highest level of analysis. Carter (1988) categorizes stylistics into different types:

1- Linguistic Stylistics: analyzing the text, focusing on language components to produce some certain stylistic effects like models for language analysis through linguistics and aesthetics.

2- Literary Stylistics: understanding, appreciating and interpreting of literary texts and knowing the intentions of their authors. The emphasis is on the importance of linguistic aspects for a better understanding of literary texts.

3- Style and Discourse: describing and characterizing the stylistic effects in a wide range of discourse types like linguistic criticism.

Literary texts like poems, stories, novels, drama, etc. express the thought of the writer. The readers of such texts have different attitudes and interpretation based on their background knowledge. Verma (2015) assures that stylistics is based on language and it is the approach that is used to make meaningful interpretation to the literary texts. Mehnaz and Khattak (2012: 97) remark that "Stylistic analysis has two main objectives: First, to enable the reader to make meaningful interpretation for the text. Second, to expand knowledge and awareness of the language in general."

Pragmatic theory is essential in text analysis. It deals with context, writer intention and the sequence of illocutionary acts. Austin (1962); Van Dijk (1977) and Beaugrande and Dressler (1986) among others stress on the pragmatic theory in text analysis which categorizes acts into different types. Austin (1962) summarizes these acts into three categories:

a- Locutionary act: directing meaning of the text consisting of several orders and ideas.

b- Illocutionary act: the purpose of the text and the intention of the writer.

c- Perlocutionary act: the effect of the text on the reader including consequences of illocutionary act.

Pragmatic and stylistic approach links the literary texts and other genres of texts to social aspects. Widdowson (1975) points out that the reader may compare and differentiate between the characters of literary texts with other similar texts to give conclusions and comments. Cultural and social aspects are considered as a bridge between literary texts and linguistic theories. Firth (1958) defines cultural stylistics as a linguistic field which includes different cultural elements like habit, customs, norms and tradition.

\section{Arab-American Poets: Mahjar Poets}

When the poet leaves his land and civilization and finds himself in different cultures and peoples, he surely composes the best poems which recall him with his beloved home. He also feels pity and compassion for his land soil. It is 
impossible to isolate his poems from his ethnic origin. It is not easy for any of them to leave his beloved home and to leave the land of civilization and to find himself in one of the youngest countries. This is what happens to Arab American Poets whose poetry is based on ethnic origin. The life in USA is challenging to them. They need to face the problems of race, religion, language, etc. which reflect their life in America, so they do not have patience and time to write long literary works like novels. They find themselves turning to poetry which needs less time and effort. Their longing to their beloved countries make poetry composing easier than other types because it helps them express themselves freely based on social and political aspects. As a result of their contact to American poets and style, ArabAmerican poets seek for some of the American poetic forms. Moreh (1976) assures that Arab-American poets try to find new forms of poetry as a result of their contact with the West by using different forms and models of Western poetry such as the sonnet and the ode. They become free of the classical Arabic form "qasida" which consists of a specific number of feet within a line. Arab-American poets use new form of poetry "free verse". This type of poetry affects Arabic poetry in terms of form and ideas. Unlike modern Arab poets, the classical Arab poets use the unrhymed and unmetered type in classical poetry "qasida". Free verse of writing poetry helps Arab-American poets express themselves freely because they focus on transferring their ideas not the form of the poem which is a heavy burden on the poets. The free verse of writing poetry is considered as a challenge and revolution against the classical poetry "qasida". Talukdar (2013: 22) emphasizes that "simple diction, style and stanzaic form with short metres and techniques of expression borrowed from drama and narratives are the hall marks of Mahjar (immigrant) poetry." Arab-American poets try to keep their native language (Arabic), traditions, customs, norms and their national ideology, so they reflect these aspects in their poetry. They respond to any cultural and political events taken place in their home countries. They also show their nation-belonging and homeland longing in their poetry.

We can say that Arab poets immigrated to North America in $19^{\text {th }}$ century helped in the development of modern Arabic poetry. They left their native countries mostly for political and economic reasons. This helped him compose great poems which included their nostalgia for the life of the past and their circumstances out their homelands. They expressed their feelings of homesickness. Abumadi (1890-1957) expresses his feeling of homesickness and remembers his homeland Lebanon by describing it as the home of the stars and he addresses his homeland in a poem entitled "the baby and the old man" as follows:

$O$, my staring homeland

Gaze, do you know who I am

I am that same boy who lives here now

Nasib Arida (1887-1946) is a famous Mahjar Syrian poet and he is a member of the New York pen association. He also expresses his longing to his beloved homeland. He composes a poem entitled (The Narration of the Experiences of Syrian Emigration) حكاية مهاجر سوري. He states the following great verse:

\section{A strange man came from the East}

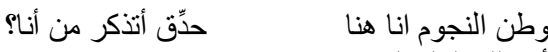

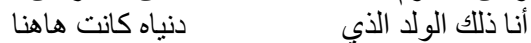

Far away from the fervor of beloved ones I lived

Zaki Qunsul (1916-1994) is a Syrian writer who immigrated to Argentina. He remembers his childhood in Yabrud, a Syrian village where he was born. He shows his homesickness in the following verse:

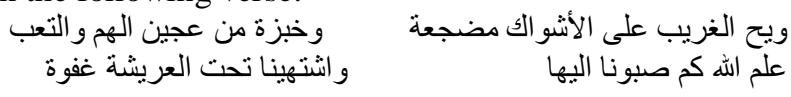

O stranger on the thrones is lying

His bread is from the dough of troubles and exhausting

Allah knows how much we like it (Syria)

And liked a nap under the Pergola

Gibran (1883-1931) shows his homesickness and belonging to the East and he also shows his love and admiration for the West:

No matter how many days, I stay away

I shall remain an Easterner.

Easterner in my manners,

No matter how much I admire Western progress.

The paper sheds light on four prominent poets who are members of Al-Rabita Al-Qalamiyya "The pen Association": Khalil Gibran (1883-1931); Elia Abumadi (1890-1957); Ameen Rihani (1876-1940) and Mikhail Naimy (1889- 1988). The pen Association helps widely in modern Arab literary renaissance. The paper also analyzes some of their poems based on the stylistic Approach.

\section{KHALIL GIBRAN (1883-1931)}

Gibran Khalil was born in 1883 in Bsharri, a Lebanese mountain village. He met some of Mahjar (emigrant) writers like Rihani, Naimy and Abumadi. They formed Al-Rabitah Al-Qalamiyah (The pen Association). Gibran was the important figure in establishing "The pen Association" which helped in the development of modern Arabic literature. 
Jafarov and Ibrahimove (2013:201) state that "the members of the pen Association were in a favor of writing not in classical Arabic language, but in modern simplified one. Thus, they tried to clean up the Arabic language from archaic words." Gibran wrote in two languages: English and Arabic. His first writings were in Arabic for some journals in New York City which were published for Arab immigration people living in North America. One of his prominent works was the "prophet book". During the $20^{\text {th }}$ century, the prophet book was the best-selling book in America. It was written in simple English and it was translated into more than twenty languages. It is also said that 9 million copies were sold in the United States. It was a proof to the genius of Gibran. The book is a collection of parables, sayings and it contains some of philosophical issues. It is considered the book of wisdom because it deals with different issues occurred in the society.

In the poem "On Children", Gibran conveys advice and wisdom to the readers as follows:

Your children are not your children.

They are the sons and daughters of life's longing for itself.

They came through you but not from you.

Gibran in the poem uses simple English that is easily understood. He calls for controlled children freedom because children ought to have their own identity. Parents could not oblige and control their children in choosing religions, careers and other things, so they are children of life and circumstances. Gibran wants to convey a message that parents should avoid overprotection of their children. They should depend on themselves and to be given the opportunities to solve their problems and difficulties and to find effective solutions for their mistakes. In Arab world, parents mostly have tended to keep their children and ask them to avoid things that the parents think they are not suitable to them. Parents' guide and support are essential for their children provided that such guidance and support do not affect negatively in building their children's characters.

Two major issues ought to be taken into consideration when analyzing any poem: (a) Interpreting and understanding the poem based on the dimension of the discourse situation; (b) decoding the author's intention. Elnaili (2013: 11) assures that "the goal of most stylistic studies is not only to describe the linguistic form, but also to demonstrate the significant function for the interpretation of the text." Gibran in his poem "My Soul counseled me" (و عظتني نفسي) refers to good and evil by creating an image of a dialogue between his soul and himself as a form of advice given to him from his soul and later he transfers such advice to the readers. The observation to be seen in this poem is the use of symbolism and literary figures. The poem touches the heart of the readers because they receive advice which helps them in their life. Gibran uses the allegory to cover different issues relating to love, beauty, life secrets, happiness, time, equality, etc. The poem is concerned with the poet's repentance which is followed a straying. Gibran finds the truth, goodness and right which are given to him from his soul as advice after going astray .He is seeking with a puzzle and surprising for the nature of human being and the secret of the existence in order to reach the supreme ideals .The poem discusses two types of love. One is the surface love which focuses on wishes and instincts. Such love may give a negative effect on human life because it fosters the selfishness. The other one has a decisive effect on human life. It is Sufi love which goes with human being to supreme and ideal levels. It is the love of God, charities, human beings, equality, etc.

The poem "My Soul counseled me") shows the importance of aphorisms and allegories. It goes with human soul to supreme status. It tries to create an ideal city which is full of love, honest and understanding in place of noisy and sad city which is full of pain, oppression and inequality following the literary works written by William Shakespeare, William Blake and others. The poem "My soul counseled me" also insists to dissolve the religious and social differences among people because the human being is the core of universal and existence. Gibran uses free verse as a reaction against classical Arab poem "qasida". Qasida in classical Arab poems uses the monorhyme and divides the verse of the poem into two hemistiches and monorhyme like the poems of Imru' Al-Qays. Al-Ma'ani (2012: 80) remarks that "the use of the new poetry, free verse, had led to an eruptive change of form and content. In terms of form, modern Arab poets managed to do away with unirhyme and unimeter scheme of the classical Arabic form"

Modern Arab poets like Gibran avoid using the rigid unirhyme in order to express themselves freely. This technique of using free verse touches the demands of the Mahjar poets because they are dealing with new philosophical and current issues. Talukdar (2013) emphasizes that Mahjar poets revolted against the classical metric measurement style to free verse which is simple diction with short meters and easy language. They wanted to make Arabic literature more friendly to the readers and easy to be understood. This technique also makes modern Arab poems coherent and united with easy language. Following this technique, Gibran creates beautiful images and expresses his vision, emotion and philosophical ideas easily and freely. In one of Gibran's poems "Al Mawakib" (processions), he insists that people are created with evil and they have evil souls. He adds that people do not offer charitable deeds by their own choice, but they do so if they are obliged to do so. The first verse in this poem is as follows:

Good in people is made if they are obliged to do so

الخير في الناس مصنو في إذا جُبروا و الثر في الناس لا يفنى و إن قُبروا

and evil in people is not lost even if they are buried.

Gibran in this poem has negative view and attitude towards human soul. In the same poem, Gibran also has negative view towards the surface love. He compares it to grass in the field without flower and fruit as follows: 
Love in people takes different forms

و الحب في الناس أثنكالُ و أكثرها كالعشب في الحقل لا زهرٌ ولان ثمر

like grass in the field;

there is no flower and fruit.

Unlike Al Mawakib (procession) which gives negative views towards human soul and surface love, Gibran gives a positive view towards the soul which is the source of inspiration in the poem "My Soul Counseled Me" (و عظنتي نفسي). Gibran's soul advises him to get rid of bad and evil deeds. His soul preaches him to love what people hate and to befriend with those who revile him. Gibran starts his poem with a supreme philosophical view of love:

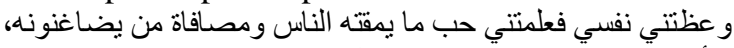
و أبانت لي أن الحب ليس بميزة في الدحب بل في في في النحبوب

\section{My soul spoke unto me and counseled me to love all that others hate \\ And to befriend with those whom others defame \\ My soul counseled me and revealed unto me that love dignified \\ not alone the one who loves, but also the beloved}

Translated by Ghareeb (1988: 30)

Gibran points out that his soul advises him to see the hidden beauty. It teaches him to think carefully about what people call and see ugly and to meditate upon what is seen bad. Gibran wants to convey a message to the reader that he should take any decision by his own without the interference of others. He should not follow what people think .He adds:

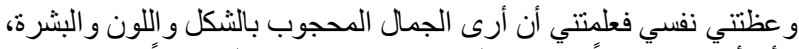

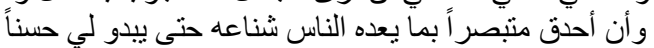

My soul counseled me and taught me

to see beauty veiled by form and color

My soul charged me to gaze steadfastly upon all

that is deemed ugly until it appears lovely

Translated by Ghareeb( 1988: 30).

Gibran's soul guides him in a form of advice how to look at real beauty because beauty means different things to different people. What people see ugly may be beautiful in the eyes of others. The advice is to look carefully at things before deciding whether they are beautiful or not. Gibran wants to tell the readers that beauty is in the eye of the beholder. Gibran's soul preaches him and teaches him about different issues like silence, hearing, praising, blaming, time and humble. The soul in this poem is the source of inspiration and wisdom which preaches the poet and the readers to avoid hatred and evil deeds and it calls for virtue, excellence and good deeds. Gibran in his turn transfers the advice of his soul to the readers because they are alike and each of them ought to follow the positive advice of his soul.

\section{ELIA ABUMADi (1890 - 1957)}

Abumadi was born in 1890 in a Lebanese village "Al-Maidassa. He pursued his education in Cairo. He published his first book of poems entitled" Remembrance of the past" in 1911. He moved to New York City in 1916 where he met and married Dora Diab whose father was the editor of the first Arabic newspaper in America. Gibran published different distinguished books of poetry in the United Sates like: Al-Jadawil (The Brooks) in 1927 and Al-Khama'il (The Thickets) in 1940. Unlike other Mahjar writers, Abumadi was the least known in America because he wrote all of his works in Arabic. Unfortunately, his wife Dora Diab did not read any of his work because she knew no Arabic. He focused on his poems on skepticism and hope. He added a philosophical dimension to Arab modern poetry.

One of the features of Abumadi's poems is nostalgia. He suffered the alien, isolation and bitter exile regardless the money he gained. He considered himself as a prisoner in a jail. He expresses his love to his homeland Lebanon in the poem Ghost (شبح):

Lebanon do not despise your children because they rode and

$$
\text { لبنان لا تعدل بنيك إذا هم ركبوا إلى العلياء كل سقين }
$$

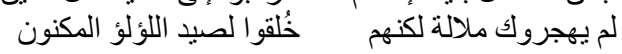

ascended to the height everything. They do not abandon you, but

they do so because they are created to pearl fishing.

Abumadi was given the chance during his stay in America to acquire American culture and Western civilization. He compared them to Arabic ones. Accordingly, he built a clear character which helped him compose poetry dealing with different issues like good, evil, aspects of life among others. In a poem entitled "أيهذا الثاكي" (O, Complainant), he criticizes a group of people who are complaining from everything. He advises them to enjoy the beauty of life and nature and he addresses them as follows:

O, complainants who complain without any pain.

$$
\begin{aligned}
& \text { أيهذا الثاكي وما بك داء كيف تغدو إذا غدوت عليلا }
\end{aligned}
$$

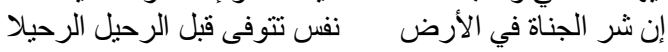

How will you behave if you become with pain. 
The worst on earth is who think

for death before it is the time.

Abumadi also addresses people to leave troubles and to enjoy the beauty of life and see the positive side of life. He is against pessimists:

He said with complains the sky is sad and frowned.

$$
\text { قال السماء كئية وتجهماً قلت ابتسم يكفي التجهم في السماء }
$$

I said: smile! Enough frowns and sad in the sky.

The lengthiest poem in Abumadi's book Al-Jadawil "The Brooks" is "الطلاسم" (Riddles or Vague Issues). It is considered the peak of Abumadi's success. It covers many mysterious issues which have no accurate answers. It also describes Abumadi's failure of understanding the secret of life. He goes side by side with the trends of agnosticism. The poem has seventy-one quatrains ending with Abumadi's perplexity and his inability to find the correct answer. The poet discusses different topics in the poem like universe affairs and its creator, Man and its destiny, Monastery, the sea, Tombs, Huts, Castles and struggles. It is nearly the first poem in Arabic literature which touches and dialogues the human thought. Abu-Madi starts his poem by raising the issue of the existence as follows:

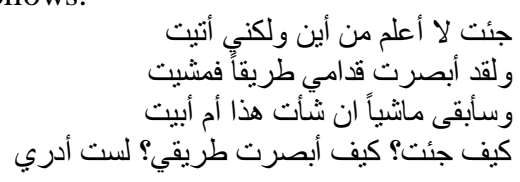

I came

Not knowing

My feet saw the way

And I walked there

And I shall continue

Whether I so desire or not

How did I come?

How see the path?

I know not

Translated by Ghareeb (1988: 74).

In the verse stated above, Abu-Madi raises different vague issue that he comes to life without knowing from where he comes, but in any way he comes. He does not have the right of choice. To him, his existence in the life is mysterious. He does not know the real truth of his existence. He admits his inability and lack of knowledge about Man's existence. He is obliged to walk in the path he sees in front of him, but he knows nothing about how he comes and how he sees his own path. The reader can conclude the following philosophical question from the verse stated above.

Is Man created and existent in another world before his coming to life or he is existent at the time of birth?

Abu-Madi adds in his poem:

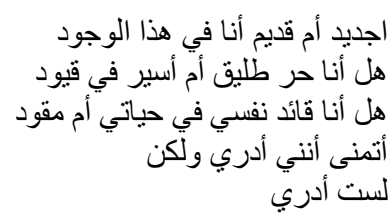

Old or new

is this existence?

Am I free

or fettered

Do I lead myself

or am I led?

I wish I know

I do not

Translated by Ghareeb (1988: 74).

Abu-Madi refers to the controversial issue "transmigration (metempsychosis) of soul. The following questions may be raised as a reaction to the verse stated above:

a- Is Man free or not? Is he compulsory coming and going?

b- Is the existence of Man a puzzle and riddle?

Abu-Madi is unable to find answers to these questions, so he goes to the nature where he may find answers to his questions. He asks the sea about some strange phenomena, hoping he may find clarification to them:

$$
\begin{aligned}
& \text { قد سألت البحر يوماً هل أنا يا بحر منكا؟ }
\end{aligned}
$$

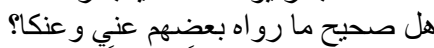

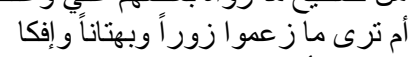

$$
\begin{aligned}
& \text { ضحكت أمو اجه مني وقالت زورات } \\
& \text { لست أدري }
\end{aligned}
$$




\author{
I asked the sea \\ Do I come from you? \\ Is it true \\ What some say of you and me? \\ The waves laughed \\ And called: I do not know
}

Translated by Ghareeb (1988: 74).

The verse stated above refers to the relationship between the creatures and the sea which could be the source of human life. He refers to Darwin's theory of evolution. He asks the sea about the origin of human being and whether the source of human being is a sea germ as Darwin claims or it is just lies. The waves of the sea metaphorically laugh at him and say I do not know.

Abu-Madi decides to consult the monastery about the secret of life:

I entered the monastery

To question the monks

Only to find them

As bewildered and amazed

As I am myself

Despair overcame them

And found them submissive

Lo, on the door is written: I do not know

Translated by Ghareeb (1988: 74)

Abu-Madi thinks that the monks may realize the secret of life and they can easily answer the issues and questions raised, but they fail to answer them. They are despair and submissive. As a symbol of their failure, Abu-Madi finds the sign "I do not know" written on the door of the monastery. No one can understand life and it is an indication that the human being is weak and has limited abilities. There is a superpower represented by Allah who controls our life and nature. Abu-Madi concludes and conveys a message that life is a riddle and mysterious.

\title{
V. AMEEN RiHANi (1876-1940)
}

Ameen Rihani was born in 1876 in Freik, Lebanon. His father sent him to New York city in 1888 to learn the principles of English. He studied the writings of great American and European writers like Shakespear, Hugo, Darwin, Spencer, Voltaire, Emerson and Byron. Rihani was a prominent writer because he had diversity of talents. He was essayist, novelist, philosopher and poet. He linked his writings with Arab civilization. Karam (2013: 488) states "Rihani (1876-1940) is a pioneer of modernization, globalization and universalism. Due to his civilization upbringing, and after oscillating between the two contradictory realms of the East and west since the age of twelve, he became obsessed with fostering social reform." He was interested with the poetry of Abul'ala' Al-Ma'arri. Accordingly, he translated his poetry which was based on skepticism. Rihani found skepticism a rich area to write about. He wrote different types of writings in English and Arabic. In Arabic, he wrote different essays and letters like "The Rihani essays" (Al-rihaniyyat), Nationalism (Al-Qawmiyat) and Literature and Arts (Adab wa Fan). He wrote different articles about historical and political analysis like Treatise of the French Revolution (Nabtha fih Athawra Al-Faranciya) and Disasters (An-nakabat). He also wrote short stories like "The Muleteer and the Monks (Al-Makari wal Kahen); novels like The Lily of Al-Ghore (Zanbakat al Ghore); poetry like Hymn of the Valley (Hutaf Al-Awdiya). Rihani wrote different works in English: plays like the book of Khalid; essays like the path of vision; poetry like the quatrains of Abul'ala' Al-Ma'arri. He also wrote different articles about Arab society to the American readers. He published them in New York Times, Harper's Magazine and Atlantic Monthly and the Nation. Rihani in these articles called for freedom and dignity. He insisted that Arab people should understand the Western democratic society in order to build their societies accordingly. He asked for equality among the people of the world regardless religions and races. The following verse is taken from "A Chant of Mystics"

We are not of the East or the West

No boundaries exist in our breast

we are free

Nor crescent nor cross we adore

Nor Budha nor Christ we implore

Muslem nor Jew we abhor

We are free 
We can conclude from the verse stated above that Rihani calls for unity between Arab world and the whole world. To unite our nations with the world, we should avoid ethnic and class discrimination so that the minorities should not be harmed and they should also take their rights. The ethnic or religious minorities should feel secure and comfortable in their societies. Rihani assures that each member in the society regardless of his religion or ethnicity should be given an equal opportunity as others. He is against the struggle of civilizations which lead to wars and disasters. He believes in liberal side which focuses on the idea of world citizen, so we people of the world are not of the East or the West.

Rihani wants to acquaint the Arabs with their unique heritage. He is proud because he comes to America from the East which has rich civilization and it is the cradle of religions and civilizations. He adds that Arab civilization helps in building the Western one. He concludes his thought in the following verse taken from a poem entitled "I am the East"

I am the East

I am the corner stone

of the first temple of God

and the first throne of Humanity

I am the East

I possess philosophies and creeds

so who would exchange them with me for technology.

Rihani asserts his pride to the East. He shows his adherence and love to Eastern civilization. Rihani gives his loyalty, his belonging and identity to the East which is the cradle of civilizations and cultures. Gibran stresses this view in "secrets of the Heart: 19". He states that the culture of the West is not better than the East because both cultures are important and complete each other. Rihani and Gibran show their belonging and adherence to both cultures. They remark that Eastern culture plays a decisive role in the development of Western civilization and provides the West with scientific heritage since the dawn of history. Rihani wants to give a hint for Western readers about the role of the East in developing their culture. The West benefits from the Arab scientists like Al-Ghazali's theory of causation; Ibn AlHaytham's mathematical works; Al-Khawarizmi's algebra and logarithm theories; Ibn Sina's medical works; Ibn Rushd's physical and philosophical theories; Al-Mas'udi's evolution theory and they also benefit from the Arab art of architecture.

\section{MiKhail NAIMY (1889-1988)}

Naimy was born in 1889 in Biskinta in Lebanon. He died in 1988 at the age of ninety-nine. In 1912, he pursued his higher education at the University of Washington, joining his brother who was living in the United States. During his study at the University, he wrote different articles and topics on criticism. He also wrote short stories which were published in the Mahjar journal "Al- Funun". Naimy served with US military army in the First World War. He was sent to the French front during the war. This gave him a motive to study French history and literature and later to compose an important war poem entitled "My Brother" (أخي), he wrote a collection of twenty-two of critical literary works in Arabic which were considered the greatest service to Arabic poetry. These literary works were gathered in a book under the title "The Sieve" (الغربال) in 1923.The Sieve was considered by literary critics as a prominent book on literary criticism. It shed light on the major principles of the Mahjar poet movement as a reaction against the classical poem "qasida". In 1943, most of other Naimy's literary works were collected in one book named "Eyelid Whisperings" ( wa (الجفون). He also gave his vision about the community life after the expected war "Third war" in a book entitled "Beyond Moscow and Washington" which was published in 1957.

One of Naimy's prominent Arabic Poem is "My Brother" (أخي). The poem reflects his experience as an American soldier of Arab origin who was fighting in the First World War. The poem is written after the war. It is published in his book "Eyelids Whisperings" (همس الجفون). It focuses on the Arab situation after the First World War. The poem is prominent in the field of Arab literature because of the eloquent language used and the effective vision of the poet. He wants to describe the Arab loss after the war. Arabs participated in the First World War seeking dignity and better life. They played a decisive role in the war, but the west did not appreciate and understand their role and sacrifice. Naimy addresses his Arab brother as follows:

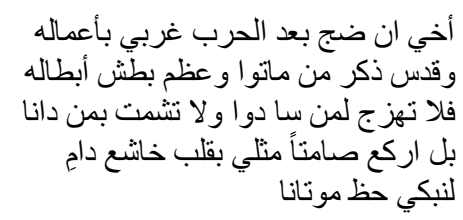

Brother, if on the heels of war Western man celebrates his deeds

Consecrates the memory of the fallen

And builds monuments for heroes,

Do not yourself sing for the victors nor rejoice

over those trampled by victorious wheels

Rather kneel as I do, wounded, for the end of our dead

Translated by Elmusa and Orfalea (1988: 59) 
Naimy addresses his Arab brother to remind him of the Arabs' suffering after the war without the appreciation of the west. He, for rhetoric reason, deletes the vocative particle (يا)"ya" and starts in a condition as follows:

Brother, if on the heels of war Western man celebrates his deeds.

$$
\text { أخي إن ضج بعد الحرب غربي بأعماله }
$$

The answer of the condition is stated as follows:

Do not yourself sing for the victors nor rejoice

$$
\text { فلا تهزج لمن سادو او لا تشمت بمن دانا }
$$

In this verse, Naimy gives the solution for the Arab brother what to do. He asks him to kneel and weep our dead. He also asks his Arab brother to be careful and to be not happy if a Westerner brags because of his victory in the First World War and glorifies the memories of his brave soldiers because Arabs sacrifice in the war without any rewards and without the West appreciation. We should kneel silently in order to weep over the misfortune of Arab dead soldiers who sacrifice for the case of Arab dignity and progress. We can do nothing for our dead brothers more than bowing and weeping silently. Naimy emphasizes that the West glorifies and sanctifies the memory of their dead and the oppression of their soldiers although this comes as a result of human pain and destruction. He also gives a miserable image after returning the warriors to their homelands:

Brother, if after the war a soldier comes home

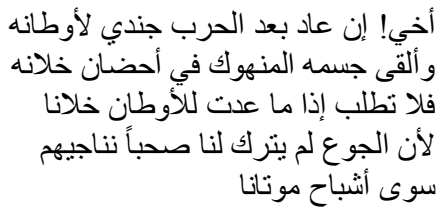
and throws his tired body into the arms of friends,

Do not hope on your return for friends

Hunger struck down all to whom we might whisper our pain.

Except the ghost of our dead

Translated by Elmusa and Orfalea (1988: 59).

Naimy in the second verse gives the miserable social relations among the people after the war represented by the return of the warriors to their homelands and families. If the warrior returns to his homeland after the war and he tries to find friends and pals, he will find nothing other than hunger, destruction, loss, famine, diseases and the miserable life. The warrior thinks that he may find comfort and ease in his homelands after escaping from the claws of death, but instead, he finds the ghosts of dead. Naimy wants to transfer an important message to the readers that wars leave destruction, despair, hunger and hatred. He wants to assure that no one wins in the war. All the combats are losers because wars are against humanity so that people must avoid wars and solve their struggles by peace means for the sake of humanity and innocent people. Naimy emphasizes his message in the third verse as follows:

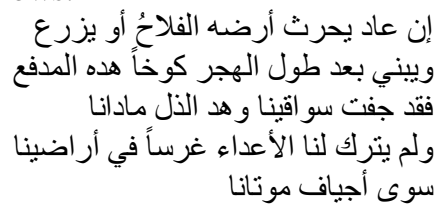

\section{Brother, if the farmer returns to till his land \\ And after long exile rebuilds a shack \\ Which cannon had wrecked \\ Our waterwheels have dried up \\ And the foes have left no seedling \\ Except the scattered corpses}

Translated by Elmusa and Orfolea (1988: 59)

The poet also addresses his brother in the style of condition in the form of not using the conditional particle (إذإ) (if). For rhetorical reason, Gibran uses (إن) (lit) (if) as a decisive way of stressing and conveying the ideas. The war ends and the farmer wants to rebuild houses and work in his farm and sows it. He wants to rebuild a cottage of the farm after a long exile. He cannot do so as a result of the destruction of the war. The answer of the condition comes in the third line of the verse. The waterwheels had drained and our dwellings collapsed by the war. He may use the metaphorical meaning that our life has collapsed by disgrace and inferiority. The enemy does not leave any plant in our lands other than the corpses of the dead and the disgrace. According to the current situation, the best to do is stated in the following verse:

Brother, misery nestled everywhere through

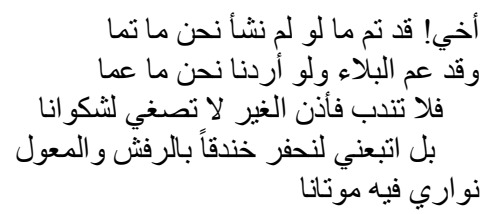


Do not lament. Others do not hear our woe.
Instead follow me with a pick and spade that
we may dig a trench in which to hide our dead.

Translated by Elmusa and Orfalea, 1988: 59.

Naimy addresses his Arab brother that the disgrace and misery are everywhere in our countries. We could have the ability to stop the calamity by ourselves not by the help of others who do not appreciate our sacrifice. We should blame ourselves because no one in the world may support us or hear to us. We should collaborate in order to solve our troubles and problems by ourselves. The poet refers to the miserable situation of the Arab world after the war. He states no one may touch our calamity and catastrophe. It is a reference to Arab's submission and humiliation after the war. As a result of the miserable situation, Naimy asks his Arab brother to follow him with axe and spade to dig our brothers' graves who are everywhere in our lands. He gives a symbolic image that pain and despair are everywhere in our countries and the corpses of our people are lying in their graves without glory and dignity because they gain nothing. He may ask his Arab brother as a metaphorical image to follow him in order to dig graves for all Arab people to get rid of the shame and disgrace. The real intention of Naimy is to give a shock for Arab people in order to urge them to restore their glory and dignity and to be counted and effective in the world. It is a remark for glorious future.

\section{CONCLUSION}

During the late $19^{\text {th }}$ century, many Arabs emigrated to North and South America for better life and conditions. Some of whom had an interest in Arabic and English literature. The place of emigration was a rich area for them to write about their homelands and Arab issues. It was the place of inspiration for them to compose great poems with free verses which helped them express their ideas and feelings freely and easily. Khafaji (1986) states that Arabic countries were under the crisis of authoritarian rules, so large group of Arab countries immigrated to North and South America. Their feelings and sadness towards their homelands were reflected in their poems. Some of the prominent emigrant (Mahjar) writers like Khalil Gibran, Ameen Rihani, Mikhail Naimeh among others established literary organization entitled AlRabita al Qalamayya (The Pen Association). The Pen Association played an important role in modern Arab literary renaissance. The love of Mahjar writers to their homelands and their feeling of homesickness gave them the opportunity to compose great poems. Jokandan and Shakib (2015: 427) states "Mahjar poets' feelings towards the distant lands far from home and worry and sadness were expressed in poetic form."

The Mahjar poets built links and bridges between East and West literature specifically poetry. Some prominent Arab emigrant poets (Mahjar Poets) who contributed in developing modern Arabic poetry were Amin Rihani, Khalil Gibran, Mikhail Naimy, Elia Abumadi , Etel Adnan, Samuel Hazo, Naomi Shihab among others.

\section{REFERENCES}

[1] Al-Ma'ani, R. A. (2012). “T.S. Eliot's Influence and Badr Shakir Al Sayyab's Individual Talent in "A City without Rain”,", International Journal of Arts and Commerce, vol. $1 \mathrm{~m}$ No.2: 78 - 89.

[2] Austin, J. (1962). How to Do Things with Words, London: Oxford.

[3] Beaugrande, R. and W. Dressler. (1986). Introduction to Text Linguistics, London: Longman.

[4] Carter, R. (1988). Direction in the Teaching and Study of English Stylistics, M. Short (ed.), Reading, Analyzing and Teaching Literature, New York and UK: Longman Group.

[5] Elmusa, S. and G. Orfalea. (1988). My Brother, in G. Orfalea and S. Almusa (ed.), Grape Leaves: A Century of Arab American Poetry, Salt Lake City: University of Utah Press.

[6] Elnail, S. (2013). A Stylistic of Libyan Short Stories: The Connotation of Adjectives, Unpublished MA Thesis, Loistana State University.

[7] Firth, J. R. (1958). Papers in Linguistics, London: OUP.

[8] Ghareeb, A. (1988 a). My Soul Counseled Me, in G. Orfalea and S. Elmusa (ed.), Grape Leaves: A Century of Arab American Poetry, Salt Lake City: University of Utah Press.

[9] Ghareeb, A. (1988 b). Riddles, in G. Orfalea and S. Elmusa (ed.) Grape Leaves: A Century of Arab American Poetry, Salt Lake City: University of Utah Press.

[10] Jafarov, V. A. and S. Ibrahimova. (2013). "Literary Societies that Played an Important Role in the Development of Arabic Mahjar Literature", International Journal of Humanities and Social Science, V. 3 No. 14: 200 - 206.

[11] Jokandan, M., S. and Mohammad S. (2015). "Reviewing Social Values in Mahjar Literature", International Journal of Current Life Sciences, Vol. 5, No. 3: 427 - 431.

[12] Karam, S. (2013). “Ameen Rihani’s Visionary Support for Women a Century Ago”, International Journal of Social Sciences and Humanity, vol. 3, No 5: $488-493$.

[13] Khafaji, M., A. (1986). Qesat Al-Abad Al-Mahjary, Beirut: Dar Al-Kottob Al- Lobnany.

[14] Mehnaze, M. and Mohammad A. Khattak. (2012). "The Role of Stylistics in Interpreting Literature", City University Research Journal, V. 2, No. 1: $97-102$.

[15] Moreh, S. (1976). Modern Arabic Poetry 1800 - 1970: The Development of its Forms and Themes under the Influence of Western Literature, Leiden: E. J. Brill.

[16] Talukdar, M., R. (2013). “Arabic Migration Literature of America”, The Ech, vol. I, Issue III: 20 - 24.

[17] Van Dijk, T. A. (1977). Text and Context: Explorations in the Semantics and Pragmatics of Discourse, London: Longman. 
[18] Verma, M. H. (2015). “A Stylistic Approach to Teaching Literature at the College Level”, Language in India, vol. $15: 8: 333$ 342.

[19] Widdosan, H. G. (1975). Stylistics and Teaching Literature, London: Longman.

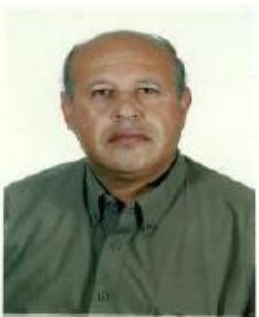

Ibrahim Mohammad Abushihab was born in Jordan 1958. He got his BA in English and MA in TEFL from Yarmouk University/Jordan (1986), whereas PhD degree in Applied Linguistics was received from Gazi University/Turkey (2003). Over the past 30 years he has been teaching English as a foreign language to Arab students in the Ministry of Education in Jordan, Aljouf University (Saudi Arabia) and Alzaytoonah Private University of Jordan. Since then, he has been doing research in the field of Linguistics, Discourse Analysis, Stylistics, Applied Linguistics and Contrastive Analysis. Dr. Ibrahim Abushihab is a Professor of Applied Linguistics at Alzaytoonah University of Jordan. 